\title{
In Silico Molecular Docking Analysis of Natural Pyridoacridines as Anticancer Agents
}

\author{
Vikas Sharma, ${ }^{1}$ Prabodh Chander Sharma, ${ }^{1}$ and Vipin Kumar ${ }^{1,2}$ \\ ${ }^{1}$ Institute of Pharmaceutical Sciences, Kurukshetra University, Kurukshetra, Haryana 136 119, India \\ ${ }^{2}$ Department of Pharmacy, School of Chemical Sciences and Pharmacy, Central University of Rajasthan, \\ Ajmer, Rajasthan 305 801, India \\ Correspondence should be addressed to Vipin Kumar; vipbhardwaj@rediffmail.com
}

Received 6 April 2016; Revised 20 June 2016; Accepted 15 November 2016

Academic Editor: Maria Carmen Yebra-Biurrun

Copyright (C) 2016 Vikas Sharma et al. This is an open access article distributed under the Creative Commons Attribution License, which permits unrestricted use, distribution, and reproduction in any medium, provided the original work is properly cited.

\begin{abstract}
Docking studies are proved to be an essential tool that facilitates the structural diversity of natural products to be harnessed in an organized manner. In this study, pyridoacridines containing natural anticancer pigments were subjected to docking studies using Glide (Schrodinger). Investigations were carried out to find out the potential molecular targets for these selected pigments. The docking was carried out on different cancer macromolecules involved in different cell cycle pathways, that is, CDK-2, CDK-6, Bcl-2, VEGFR-2, IGF-1R kinase, and G-Quadruplexes. CDK-6 was found to be the most suitable anticancer target for the pyridoacridines. In addition, effectiveness of the study was further evaluated by performing docking of known inhibitors against their respective selected macromolecules. However, the results are preliminary and experimental evaluation will be carried out in near future.
\end{abstract}

\section{Introduction}

Cancer is the deadliest disease and search is in progress to identify the potential anticancer drugs. The important aspect and reason for nonavailability of suitable anticancer drug lies in the fact that cancer displayed its action in human body through different pathways, comprising different cancer macromolecules, and it is very difficult for a single molecule/drug to inhibit all macromolecules at once. Some important examples of cancer macromolecules are Bcell lymphoma 2 (Bcl-2), vascular endothelial growth factor receptor 2 (VEGFR-2), cyclin-dependent protein kinase 6 (CDK-6), CDK-2, IGF-1R kinase (insulin-like growth factor 1 receptor), and G-Quadruplexes [1].

Some important examples of naturally derived anticancer compounds are Vincristine and Vinblastine from Catharanthus roseus, Paclitaxel from Taxus brevifolia, and Topotecan and Irinotecan from Camptotheca acuminata [2, 3]. Various pigments like varamine, violacein, amphimedine, fascaplysin, monascin, chinikomycin, and so forth were discovered with anticancer activity. Pigments constitute different chemical moieties like pyridine, quinoline, acridine, pyridoacridines, and so forth, which may be responsible for their biological effects [4-7]. Pyridoacridine (Figure 1) is one such moiety present in these pigments which might be responsible for anticancer effects of these pigments.

Different in vitro, in vivo, and computational methods were employed to assess the anticancer potential of drugs or chemicals. Among these methods, docking has been used widely in drug designing for cancer $[8,9]$. It is very difficult to identify the role of PCNPs against every single cancer macromolecule. So, it seems appropriate to limit the present study to some selected cancer macromolecules. Role of these macromolecules is well studied by different scientists from time to time [1] and their inhibition justifies their role in anticancer potential. In the present study, various aspects behind anticancer potential of selected "Pyridoacridine containing natural anticancer pigments (PCNPs)" were assessed. The selected PCNPs were, namely, amphimedine, deoxyamphimedine, neoamphimedine (Xestospongia and Amphimedon species), meridine (Amphicarpa meridiana), and varamine A (Lissoclinum vareau) [10-12]. Additionally, known inhibitors (KIs), that is, SU9516, pyridostatin pentahydrochloride, Palbociclib, OSI-906, HA14-1, and AG879, were docked against their 


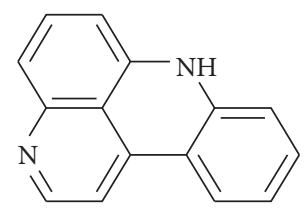

Figure 1: Basic structure of pyridoacridine.

respective macromolecule, that is, CDK-2, G-Quadruplex, CDK-6, IGF-1R kinase, Bcl-2, and VEGFR-2, in order to compare results of the study [13-19].

\section{Results and Discussion}

In the present study, PCNPs were evaluated through molecular docking studies using Glide (in silico analysis). Initially, the structures of these molecules were generated and energy was minimized. As assessed from literature survey, CDK inhibitors are strongly recommended for cancer treatment as CDKs are not necessary for the cell cycle [20]. Docking studies against CDK-2 revealed that all PCNPs (except neoamphimedine and varamine A) form $\mathrm{H}$-bonds with CDK-2. Meridine interacted with CDK-2 by forming two hydrogen bonds (Leu83, 2.427; 1.928). All PCNPs were suitably docked on CDK-2 (-5.31 to -6.21$)$ and CDK-6 (-2.9 to -9.5 ) macromolecules with promising Glide score (Figures 2 and 3$)$.

On the other hand, docked PCNPs against G-Quadruplex macromolecule showed Glide score in the range of -1.007 to 0.49 ; the reason for this poor score may be a consequence of fewer H-bond interactions. Although the Glide score is comparatively poor, visual inspection of docked ligands confirmed their binding affinity towards G-Quadruplex macromolecule (Figure 4). Interaction of PCNPs with VEGFR2 demonstrated the absence of any $\mathrm{H}$-bonding interaction while in case of $\mathrm{Bcl}-2$, varamine A surprisingly exhibits three H-bonds. Furthermore, PCNPs docked on IGF-1R kinase displayed an $\mathrm{H}$-bonding with varamine $\mathrm{A}$, meridine, and neoamphimedine with Glide score in the range of -6.7 to -4.9 .

It was noticed that studied PCNPs have different Glide score, Van der Waals energy, and coulomb energy which is apparent due to the structural difference between these natural pigments of same class. This can be exemplified from the fact that Van der Waals energy value for CDK-6 and CDK-2 inhibitors was among the lowest for almost all PCNPs. Such lower Van der Waals energy value denoted the impact of hydrogen bonding property of these compounds during protein/enzyme interaction [21]. It is interesting to note that PCNPs with an intact pyridine ring, namely, meridine, amphimedine, deoxyamphimedine, and neoamphimedine, have common binding site at Val101 of CDK- 6 protein as compared to varamine A. Absence of intact pyridine ring in varamine A might be responsible for its poor Glide score. The Glide score represents the best fit for a ligand in the active site of the target macromolecule and it is summarized as follows: Glide score for PCNPs was in the range of -7.16 to -9.53 (CDK-6); -5.5 to -6.78 (IGF-1R kinase); -5.31 to
-6.21 (CDK-2); -4.38 to -4.95 (Bcl-2); and -1 to 0.49 (GQuadruplex). Secondly, a closer look at each PCNP structure under study discloses that substituting methyl group on nitrogen with hydrogen atom (in case of meridine) makes meridine more suitable to form hydrogen bond with the target macromolecule as methyl group is more bulky and less polar as compared to $\mathrm{H}$-atoms.

Figure 4 represents meridine docking on G-Quadruplex macromolecule. These points indicated meridine effectiveness to be considered as prominent anticancer PCNP molecule, where potential attachment positions of meridine for testing substituents could improve the anticancer activity by increasing the corresponding affinity for the target. On the other hand, each PCNP under investigation forms H-bonds with CDK-6 macromolecule which makes CDK-6 the most suitable anticancer target for the pyridoacridines. Therefore, in the first place, all PCNPs might have an important role in CDK-6 inhibition [20].

Different bonding interactions are shown in Table 1 while from Table 2 it can be easily anticipated that meridine was best docked to CDK-6 with Glide energy of -44.78 , Van der Waals energy of -41.76 , and coulomb energy of -3.02 . In a study conducted by Lu and coworkers, carbonyl group at 4 th position of Fisetin (a CDK-6 inhibitor) formed Hbond with Val101; this is in accordance with present results where different PCNPs formed H-bond with Vallo1 of CDK6 macromolecule while varamine A formed H-bond with Lys43, that is, a catalytic residue that undergoes a large conformational change during activation of CDK- 6 by cyclin binding so it can be ascertained that $\mathrm{H}$-bonding of varamine A with Lys43 residue might activate CDK-6 macromolecule [20].

2.1. Effectiveness of the Study. Effectiveness of the study was further evaluated by performing docking of KIs against their respective macromolecule which can be assessed by comparing the interactions of "PCNPs-macromolecule complex" with "KIs-macromolecule complex." Interacting residues in both complexes are similar (like meridine-CDK6/Palbociclib-CDK-6 have "Val101" while meridine-CDK2/SU9516-CDK-2 have "Leu83") which might be a reason for their comparative Glide score while in other cases different interacting residues of KIs and PCNPs could be a reason for their contradictory Glide score (Figure 5 and Tables 1 and 3).

E-pharmacophores of different PCNPs were generated in accordance with the docked macromolecule. Important pharmacophoric sites (Table 4 and Figure 6) in each PCNP were identified by this method to highlight the various structural aspects of PCNP responsible for docking on a particular macromolecule. For example, in case of meridine docked on CDK-6 protein, numbers of pharmacophoric sites identified by e-pharmacophore were 6 while in case of meridine docked on IGF-1R kinase, the number of sites changes to 5 which signifies the role of e-pharmacophore generation.

Each pharmacophore displayed the presence of pharmacophoric sites, that is, aromatic ring (R), hydrogen bond acceptor (A), hydrogen bond donor (D), and hydrophobic 


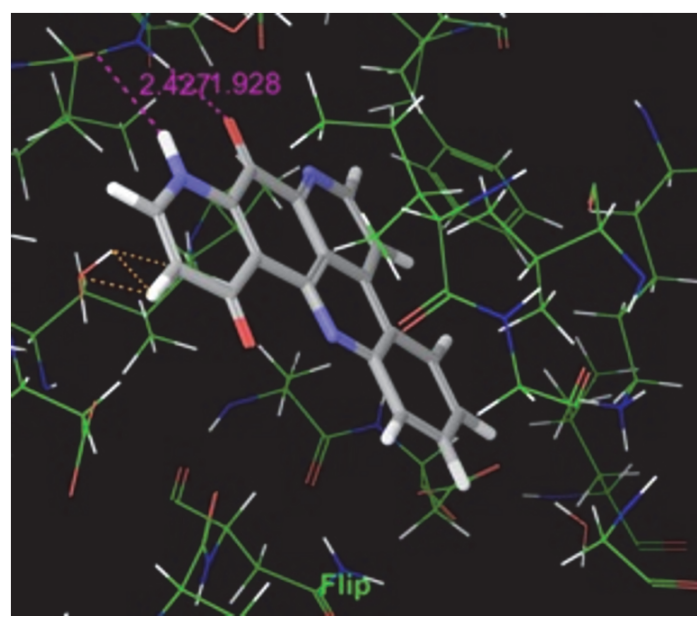

(a)

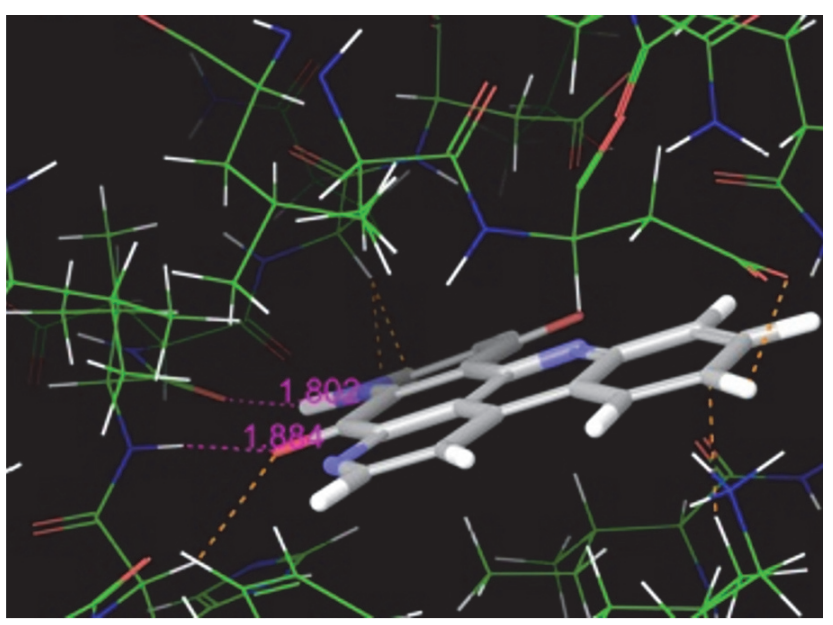

(b)

FIGURE 2: Binding models of representative PCNP (meridine) against (a) CDK-2 macromolecule and (b) CDK-6 macromolecule.

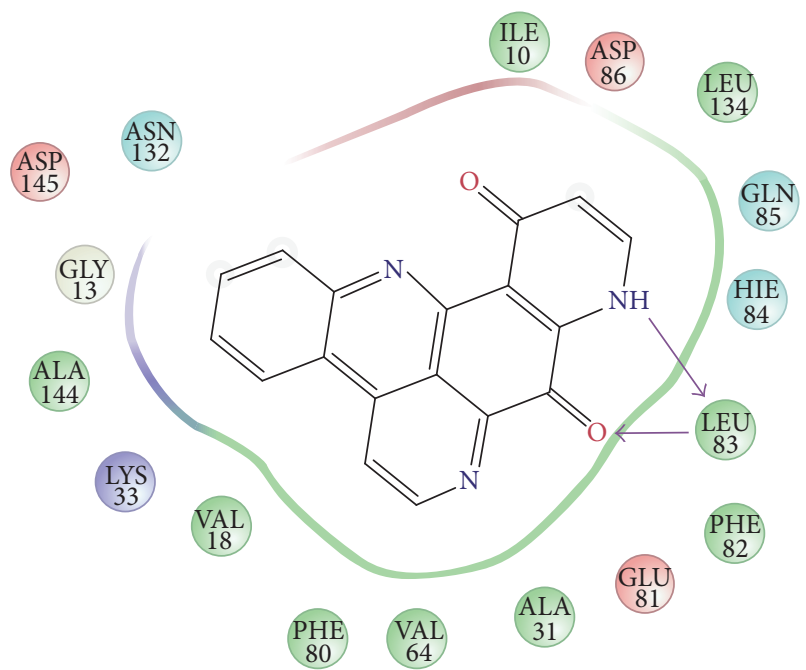

(a)

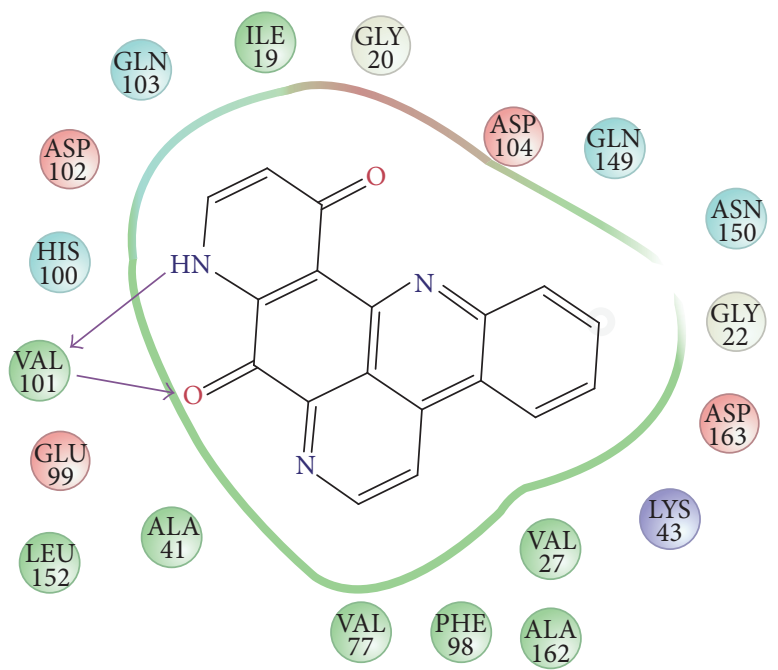

(b)

FIGURE 3: Ligand-interaction diagrams of representative PCNP (meridine) against (a) CDK-2 macromolecule and (b) CDK-6 macromolecule.

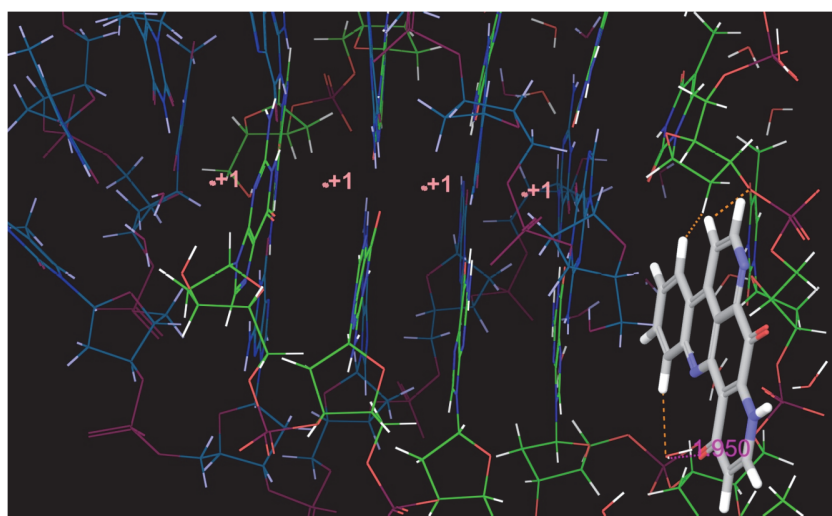

FIgURE 4: Meridine docked on G-Quadruplex macromolecule. group $(\mathrm{H})$, as per their activity/affinity towards that particular macromolecule. Similar results were obtained on generating e-pharmacophores of each docked PCNP on a specific macromolecule.

2.2. Rational Modification of Pyridoacridine Moiety. All selected PCNPs were evaluated on their specific features and were subsequently ranked as per their Glide score. From docking results, some important structural aspects which could be helpful in designing new pyridoacridine derivatives are summarized as follows:

(1) Presence of an intact pyridine ring is necessary in a PCNP molecule, as varamine A with open pyridine 
TABLE 1: Hydrogen bonding interactions and interacting amino acid residues of studied macromolecules with selected PCNPs and KIs ligands.

\begin{tabular}{|c|c|c|c|c|c|c|}
\hline \multirow[b]{3}{*}{ PCNPs } & \multicolumn{6}{|c|}{ Cancer macromolecules } \\
\hline & \multicolumn{3}{|c|}{ CDK-6 } & \multicolumn{3}{|c|}{ CDK-2 } \\
\hline & $\begin{array}{l}\text { Interacting } \\
\text { residues }\end{array}$ & $\begin{array}{c}\text { Number of } \\
\text { H-bonds }\end{array}$ & Distance & $\begin{array}{l}\text { Interacting } \\
\text { residues }\end{array}$ & $\begin{array}{c}\text { Number of } \\
\text { H-bonds }\end{array}$ & Distance \\
\hline Meridine & Val101 & 02 & $1.884 ; 1.804$ & Leu83 & 02 & $2.427 ; 1.928$ \\
\hline Amphimedine & Val101 & 01 & 2.165 & $\mathrm{H}_{2} \mathrm{O}$ molecule & 01 & 2.044 \\
\hline Neoamphimedine & Val101 & 01 & 2.196 & - & 00 & - \\
\hline Deoxyamphimedine & Val101 & 01 & 2.363 & $\mathrm{H}_{2} \mathrm{O}$ molecule & 01 & 2.036 \\
\hline Varamine A & Lys43 & 01 & 2.319 & - & 00 & - \\
\hline Palbociclib* & Val101 & 02 & $2.48 ; 2.32$ & n.d & n.d & n.d \\
\hline SU9516* & n.d & n.d & n.d & Leu83; Glu81 & 02 & $1.82 ; 2.28$ \\
\hline \multirow[b]{2}{*}{ PCNPs } & \multicolumn{3}{|c|}{ VEGFR-2 } & \multicolumn{3}{|c|}{ IGF-1R kinase } \\
\hline & $\begin{array}{l}\text { Interacting } \\
\text { residues }\end{array}$ & $\begin{array}{l}\text { Number of } \\
\text { H-bonds }\end{array}$ & Distance & $\begin{array}{l}\text { Interacting } \\
\text { residues }\end{array}$ & $\begin{array}{c}\text { Number of } \\
\text { H-bonds }\end{array}$ & Distance \\
\hline Meridine & - & 00 & - & Met1052 & 01 & 2.285 \\
\hline Amphimedine & - & 00 & - & & & \\
\hline Neoamphimedine & - & 00 & - & $\mathrm{H}_{2} \mathrm{O}$ molecule & 01 & 2.231 \\
\hline Deoxyamphimedine & - & 00 & - & - & 00 & - \\
\hline Varamine A & - & 00 & - & Gln977 & 01 & 1.915 \\
\hline AG879* & - & 00 & - & n.d & n.d & n.d \\
\hline OSI906* & n.d & n.d & n.d & Leu975 & 01 & 2.01 \\
\hline \multirow[b]{2}{*}{ PCNPs } & \multicolumn{3}{|c|}{ G-Quadruplex } & \multicolumn{3}{|c|}{$\mathrm{Bcl}-2$} \\
\hline & $\begin{array}{c}\text { Interacting } \\
\text { residues }\end{array}$ & $\begin{array}{c}\text { Number of } \\
\text { H-bonds }\end{array}$ & Distance & $\begin{array}{c}\text { Interacting } \\
\text { residues }\end{array}$ & $\begin{array}{c}\text { Number of } \\
\text { H-bonds }\end{array}$ & Distance \\
\hline Meridine & $\mathrm{H}_{2} \mathrm{O}$ molecule & 01 & 1.905 & - & 00 & - \\
\hline Amphimedine & - & 00 & - & - & 00 & - \\
\hline Neoamphimedine & - & 00 & - & - & 00 & - \\
\hline Deoxyamphimedine & - & 00 & - & - & 00 & - \\
\hline Varamine A & $\mathrm{H}_{2} \mathrm{O}$ molecule & 01 & 1.698 & $\begin{array}{l}\text { Arg143; Arg143; } \\
\text { Glu133 }\end{array}$ & 03 & $2.440 ; 2.097 ; 2.101$ \\
\hline $\begin{array}{l}\text { Pyridostatin } \\
\text { hydrochloride }\end{array}$ & $\begin{array}{l}\text { DG1011; } \\
\text { DG1009; } \\
\text { DT1007 }\end{array}$ & 03 & $2.11 ; 1.95 ; 2.35$ & n.d & n.d & n.d \\
\hline${\text { HA } 14^{*}}^{*}$ & n.d & n.d & n.d & Asp108; Arg143 & 02 & $2.48 ; 1.97$ \\
\hline
\end{tabular}

“*” represents known inhibitors of selected macromolecules.

"n.d" represents "not determined".

ring displayed poor Glide score when docked on CDK-6 molecule.

(2) Poor Glide score was observed with substitution on nitrogen heteroatom in pyridinone ring. As meridine has no substitution at nitrogen heteroatom, its Glide score is better (Glide score: -9.53 ) compared to other PCNPs (except varamine with open pyridinone ring) having substitution at nitrogen heteroatom (Glide score range: -7.66 to -2.95 ). So, order of affinity towards CDK-6 macromolecule is as follows:

(a) Meridine $>$ neoamphimedine $>$ deoxyamphimedine $>$ amphimedine $>$ varamine $\mathrm{A}$

(3) Meridine exhibits maximum number of pharmacophoric sites compared to any other PCNP when docked on any cancer macromolecule except Bcl2. Similarly, varamine A exhibited maximum number of pharmacophoric sites when docked on GQuadruplex.

(4) Presence of either hydrogen bond acceptors or donors seems to be an important structural aspect. Careful substitution of electron withdrawing or electron donating groups in pyridine ring may improve the affinity/activity of the ligand.

(5) As carbonyl group makes $\mathrm{H}$-bonding in most of the cases, its presence seems to be essential in case of PCNP lead molecule.

(6) It was also observed that more $\mathrm{H}$-bonding between ligand-macromolecule complexes makes the complex 
TABLE 2: Different glide parameters.

\begin{tabular}{|c|c|c|c|c|c|}
\hline $\begin{array}{l}\text { S. } \\
\text { Number }\end{array}$ & $\begin{array}{l}\text { Pyridoacridine analogues } \\
\text { (cancer macromolecule) }\end{array}$ & Glide GScore & Glide energy & Glide Van der Waals energy & Glide coulomb energy \\
\hline 1 & Meridine $(C D K-6)$ & -9.53 & -44.78 & -41.76 & -3.02 \\
\hline 2 & Neoamphimedine (CDK-6) & -7.66 & -34.96 & -34.82 & -0.14 \\
\hline 3 & Deoxyamphimedine (CDK-6) & -7.48 & -41.60 & -38.27 & -3.33 \\
\hline 4 & Amphimedine (CDK-6) & -7.16 & -40.63 & -41.24 & 0.60 \\
\hline 5 & Meridine (IGF-1R kinase) & -6.78 & -44.09 & -42.52 & -1.57 \\
\hline 6 & $\begin{array}{c}\text { Neoamphimedine }(I G F-1 R \\
\text { kinase })\end{array}$ & -6.48 & -41.33 & -39.44 & -1.89 \\
\hline 7 & Meridine $(C D K-2)$ & -6.21 & -40.89 & -39.54 & -1.34 \\
\hline 8 & Amphimedine $(C D K-2)$ & -6.05 & -44.34 & -41.46 & -2.87 \\
\hline 9 & Amphimedine (IGF-1R kinase) & -6.02 & -29.46 & -27.51 & -1.94 \\
\hline 10 & Varamine A $(C D K-2)$ & -5.84 & -47.92 & -42.23 & -5.69 \\
\hline 11 & Deoxyamphimedine (CDK-2) & -5.71 & -37.91 & -36.76 & -1.15 \\
\hline 12 & Varamine A (Bcl-2) & -5.63 & -35.25 & -31.74 & -3.51 \\
\hline 13 & $\begin{array}{c}\text { Deoxyamphimedine (IGF- } 1 R \\
\text { kinase) }\end{array}$ & -5.50 & -38.44 & -34.48 & -3.96 \\
\hline 14 & Neoamphimedine (CDK-2) & -5.31 & -43.00 & -40.81 & -2.18 \\
\hline 15 & Meridine $(B c l-2)$ & -4.95 & -28.73 & -28.83 & 0.09 \\
\hline 16 & Deoxyamphimedine $(B c l-2)$ & -4.94 & -31.28 & -28.66 & -2.61 \\
\hline 17 & Varamine A (IGF-1R kinase) & -4.91 & -35.32 & -31.13 & -4.18 \\
\hline 18 & Neoamphimedine (Bcl-2) & -4.47 & -28.84 & -28.34 & -0.49 \\
\hline 19 & Amphimedine (Bcl-2) & -4.38 & -28.37 & -29.58 & 1.20 \\
\hline 20 & Varamine A (CDK-6) & -2.95 & -41.06 & -39.55 & -1.50 \\
\hline 21 & Amphimedine (VEGFR-2) & -1.80 & -25.09 & -23.61 & -1.48 \\
\hline 22 & Neoamphimedine (VEGFR-2) & -1.67 & -21.12 & -19.54 & -1.57 \\
\hline 23 & Meridine (G-Quadruplex) & -1.00 & -29.99 & -25.94 & -4.05 \\
\hline 24 & Varamine A (G-Quadruplex) & -0.97 & -37.20 & -31.10 & -6.09 \\
\hline 25 & $\begin{array}{l}\text { Deoxyamphimedine } \\
\text { (G-Quadruplex) }\end{array}$ & -0.94 & -35.56 & -30.01 & -5.55 \\
\hline 26 & $\begin{array}{l}\text { Amphimedine } \\
\text { (G-Quadruplex) }\end{array}$ & 0.42 & -34.38 & -34.03 & -0.34 \\
\hline 27 & $\begin{array}{l}\text { Neoamphimedine } \\
\text { (G-Quadruplex) }\end{array}$ & 0.49 & -32.96 & -32.41 & -0.54 \\
\hline
\end{tabular}

TABLE 3: Different glide parameters of known inhibitors.

\begin{tabular}{|c|c|c|c|c|c|}
\hline S. Number & $\begin{array}{l}\text { Known inhibitors } \\
\text { (cancer } \\
\text { macromolecule) }\end{array}$ & Glide GScore & Glide energy & Glide Van der Waals energy & Glide coulomb energy \\
\hline 1 & SU9516 (CDK-2) & -8.997 & -37.781 & -32.025 & -5.756 \\
\hline 2 & $\begin{array}{c}\text { Pyridostatin } \\
\text { pentahydrochloride } \\
\text { (G-Quadruplex })\end{array}$ & -8.846 & -81.019 & -71.821 & -9.199 \\
\hline 3 & Palbociclib (CDK-6) & -8.066 & -53.366 & -49.816 & -3.55 \\
\hline 4 & $\begin{array}{c}\text { OSI-906 (IGF-1R } \\
\text { kinase) }\end{array}$ & -6.518 & -43.453 & -39.081 & -4.372 \\
\hline 5 & HA14-1 (Bcl-2) & -4.837 & -29.911 & -26.702 & -3.209 \\
\hline 6 & AG879 (VEGFR-2) & -1.832 & -18.501 & -12.745 & -5.756 \\
\hline
\end{tabular}




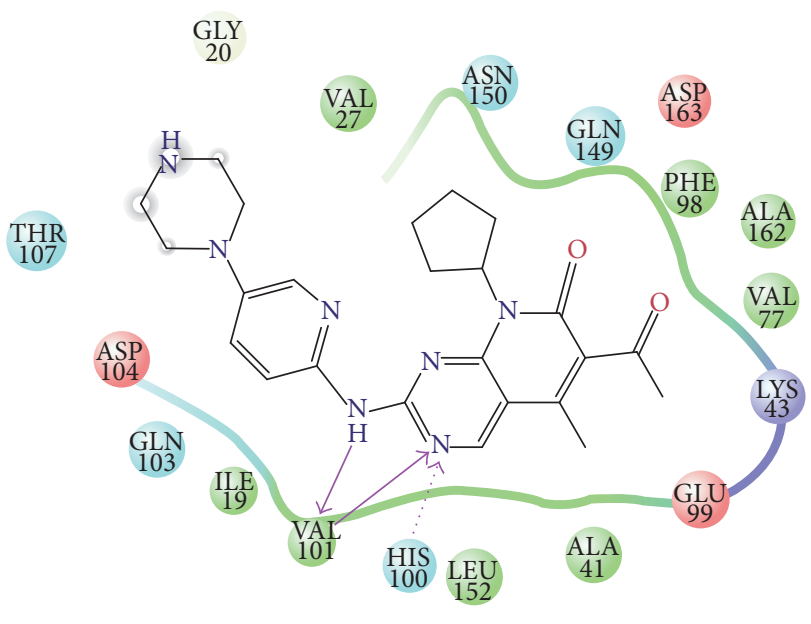

Palbociclib (CDK-6)

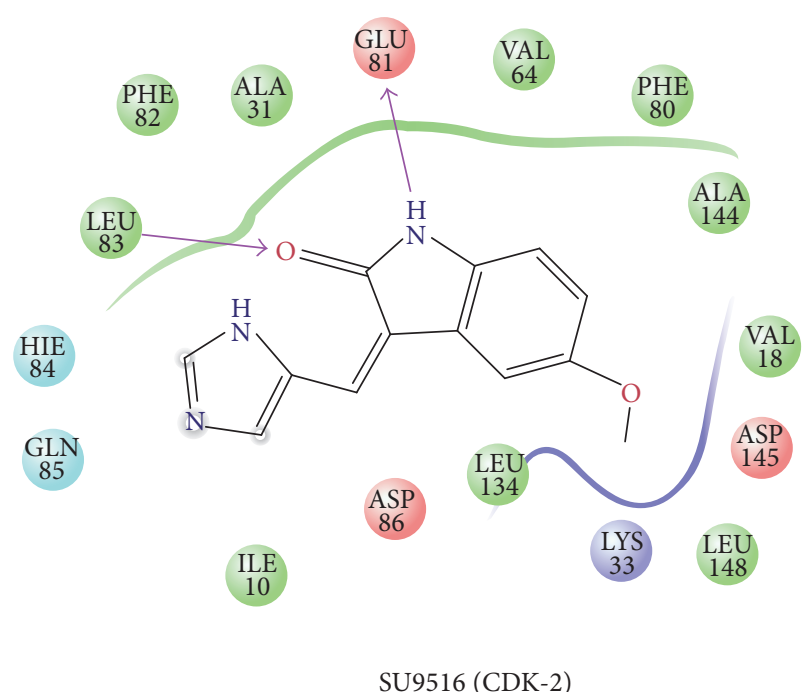

SU9516 (CDK-2)

FIGURE 5: Ligand-interaction diagrams of KIs, that is, Palbociclib and SU9516, against CDK-6 and CDK-2 macromolecules, respectively.

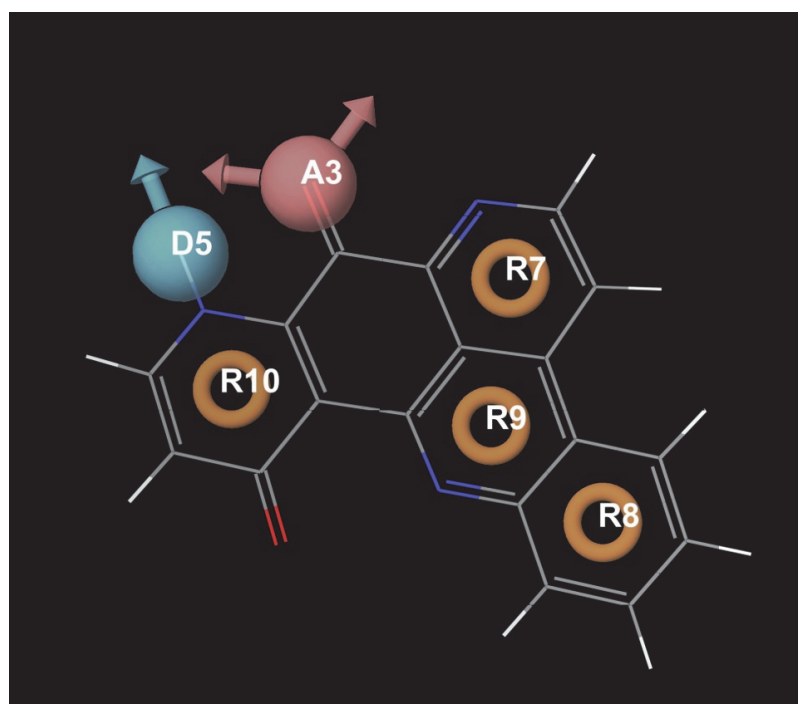

FIGURE 6: E-pharmacophore of representative PCNP (meridine) on CDK-6 macromolecule illustrating hydrogen bond acceptor (A3; pink), hydrogen bond donor (D5; blue), and aromatic ring (R7-R10; orange) features.

more stable, so use of functional groups which are known for their $\mathrm{H}$-bonding could improve the affinity and as a result could improve the anticancer action.

Based on these points, it can be asserted that appropriate modifications at meridine nucleus may provide novel anticancer derivatives.

\section{Materials and Methods}

Docking studies of PCNP ligands and KIs of selected macromolecules (Figure 7) were performed using Glide, version 5.6, 2010 [22], against the selected cancer macromolecules, where alteration of expression for each macromolecule corresponds to a different anticancer mechanism.
3.1. Ligand Preparation. It is the initial step for molecular docking studies. LigPrep module, version 2.4, 2010 [23], was used for geometrical refining of chemical structures (drawn in Maestro module) of PCNP and KIs ligands of selected macromolecules. LigPrep is intended to set up premium 3D structures with accurate chiralities. Original states of ionization were retained; tautomers and conformations were generated by the Monte Carlo method as implemented in MacroModel version 9.8, 2010 [24], using OPLS-2005 force field. The generated conformers were subsequently minimized using truncated Newton conjugate gradient (TNCG) minimization up to 500 iterations. The conformers with an energy difference of $30 \mathrm{kcal} / \mathrm{mol}$ as compared to the global energy minimum conformer were retained. The conformational searches were carried out for aqueous solution using the generalized born/solvent accessible surface (GB/SA) continuum solvation model $[25,26]$.

3.2. Protein Preparation. Protein preparation wizard of Maestro software was used for protein preparation. The protein structures, namely, 1DI8 (CDK-2), 1L1H (G-Quadruplex), 1XO2 (CDK-6), 2OJ9 (IGF-1R kinase), 2O2F (Bcl-2), and 2OH4 (VEGFR-2), were taken from Protein Data Bank [20, 27-32]. The selected chains were edited for missing hydrogens and for assigning proper bond orders. The $\mathrm{H}$-bonds were optimized using sample orientations. All the polar hydrogens were displayed. Finally, the protein structure was minimized to the default Root Mean Square Deviation (RMSD) value of 0.30 .

3.3. Receptor Grid Generation. From the defined receptor, the cocrystallized ligand was separated from the active site of receptor chain. The atoms were of size equal to Van der Waals radii of 1.0 Á while the partial atomic charge was less than 0.25 defaults. The active site represents an enclosing box at the centroid of the workspace ligand. Following this protocol, a grid centered on the ligand was generated using 
TABLE 4: Number of sites estimated via e-pharmacophores generation for different PCNPs against selected cancer macromolecules.

\begin{tabular}{|c|c|c|}
\hline S. Number & $\begin{array}{l}\text { Pyridoacridine analogues } \\
\text { (cancer macromolecule) }\end{array}$ & $\begin{array}{l}\text { Number of } \\
\text { sites }\end{array}$ \\
\hline 1 & Meridine (CDK-6) & 6 \\
\hline 2 & Meridine (IGF-1R kinase) & 5 \\
\hline 3 & Meridine (CDK-2) & 6 \\
\hline 4 & Meridine (Bcl-2) & 3 \\
\hline 5 & Meridine (G-Quadruplex) & 4 \\
\hline 6 & Deoxyamphimedine (CDK-2) & 5 \\
\hline 7 & Deoxyamphimedine (CDK-6) & 5 \\
\hline 8 & Deoxyamphimedine (Bcl-2) & 4 \\
\hline 9 & $\begin{array}{c}\text { Deoxyamphimedine (IGF-1R } \\
\text { kinase) }\end{array}$ & 3 \\
\hline 10 & $\begin{array}{l}\text { Deoxyamphimedine } \\
\text { (G-Quadruplex) }\end{array}$ & 3 \\
\hline 11 & Neoamphimedine (CDK-6) & 5 \\
\hline 12 & $\begin{array}{c}\text { Neoamphimedine (IGF-1R } \\
\text { kinase) }\end{array}$ & 4 \\
\hline 13 & Neoamphimedine (VEGFR-2) & 1 \\
\hline 14 & $\begin{array}{l}\text { Neoamphimedine } \\
\text { (G-Quadruplex) }\end{array}$ & 3 \\
\hline 15 & Neoamphimedine (CDK-2) & 4 \\
\hline 16 & Neoamphimedine (Bcl-2) & 5 \\
\hline 17 & Amphimedine (Bcl-2) & 4 \\
\hline 18 & Amphimedine (G-Quadruplex) & 3 \\
\hline 19 & Amphimedine (CDK-6) & 5 \\
\hline 20 & Amphimedine (VEGFR-2) & 8 \\
\hline 21 & Amphimedine (CDK-2) & 5 \\
\hline 22 & Amphimedine (IGF-1R kinase) & 4 \\
\hline 23 & Varamine A (CDK-2) & 4 \\
\hline 24 & Varamine A (IGF-1R kinase) & 4 \\
\hline 25 & Varamine A (Bcl-2) & 6 \\
\hline 26 & Varamine A (CDK-6) & 5 \\
\hline 27 & Varamine A (G-Quadruplex) & 4 \\
\hline
\end{tabular}

the default Glide settings. All ligands were docked into this grid structure.

3.4. Molecular Docking Analysis. On a defined receptor grid, flexible docking was performed using the extra precision (XP) feature of Glide module, version 5.6, 2010 [22]. The constraints to defined ligand-receptor interactions were not set. The structure output format was set to pose viewer file so as to view the output of the resulting docking studies from pose viewer.

3.5. Generation of E-Pharmacophore. E-pharmacophore was generated for each of the KIs as well as PCNP docked on different cancer macromolecules. The process started automatically with refined ligands where pharmacophoric sites were generated with PHASE, Schrodinger, LLC, New York [33]. PHASE uses number of features like positive ionizable group $(\mathrm{P})$, hydrogen bond acceptor $(\mathrm{A})$, aromatic ring $(\mathrm{R})$, hydrogen bond donor $(\mathrm{D})$, negative ionizable group $(\mathrm{N})$, and hydrophobe $(\mathrm{H})$. An energetic value was assigned to each pharmacophoric site on the basis of Glide XP descriptors.

3.6. Selection of the Best-Scored Pose. The best docking poses for the PCNPs were selected primarily by considering the docking scores but values of different energies, number of $\mathrm{H}$ bonds, and visual inspection of all docking poses in Maestro (Schrodinger, USA) were also taken into account. Interaction energy between protein and ligand can be related to binding affinities. Different criteria were laid down to select bestdocked structure for each ligand. Then, rankings were derived by directly using the Glide GScore.

\section{Conclusion}

From the study, two questions arise: first, which macromolecule could be responsible for anticancer mechanism of PCNPs? And second one is, which PCNP could be considered as a "lead molecule" of the future? The answer to the first question is, since almost all PCNP ligands have good Glide score except varamine A, CDK-6 can be considered as the most suitable macromolecule through which PCNPs exhibit their anticancer mechanism while in second case, it was "meridine" which bears the best Glide score for each macromolecule except varamine A. Glide score of a particular ligand describes its effectiveness against the desired target. Docking results clearly judged meridine (best Glide score, maximum $H$-bonds, and promising Van der Waals and coulomb energy between the ligand and receptor) to be a promising PCNP and it could be considered as potential "lead molecule" for the development of novel anticancer drugs. Docking results of KIs against selected macromolecules further validate our assertion behind suitability of "meridine as a lead molecule," as meridine and Palbociclib both interact with the same residue (i.e., Val101) of CDK-6 and exhibit comparative Glide scores of -9.533 and -8.066 , respectively.

From the docking results, it is quite clear that nitrogen atom substitution of the pyridine ring of pyridoacridines results in lesser Glide score which corresponds to poor binding interaction with the target macromolecule. Furthermore, the results indicate higher affinity of pyridoacridines towards CDK-6 macromolecule, which might be considered as the potential mechanism for pyridoacridines. On the other hand, among the studied pyridoacridines, meridine comes with highest Glide score against each target macromolecule which makes it an appropriate "lead compound." Some distinguished features of meridine are the following: (a) nitrogen atom of the pyridine group, (b) the presence of two carbonyl groups, and (c) presence of nitrogen (donor) alongside carbonyl group (acceptor) might decrease electron density in the region; all these features promote H-bonding with the active site of the target macromolecule which results in the high Glide score. Presence of bulkier methyl group on nitrogen atom of pyridine ring in case of amphimedine, deoxyamphimedine, and neoamphimedine with absence of pyridine ring in varamine A disfavors hydrogen bonding 
<smiles>Cn1cc2c(cc1=O)-c1nc3ccccc3c3ccnc(c13)C2=O</smiles>

Amphimedine<smiles>CCC(=O)NCCc1c(SC)c(OC)c2nccc3c2c1Nc1ccccc1-3</smiles>

Varamine A<smiles>Cn1ccc2c(c1=O)C(=O)c1nccc3c1c(nc1ccccc13)C2=O</smiles>

Neoamphimedine<smiles></smiles>

Meridine<smiles>C[n+]1ccc2c(c1)C(=O)c1nccc3c1c-2nc1ccccc13</smiles>

Deoxyamphimedine<smiles>COc1ccc2c(c1)/C(=C\c1cnc[nH]1)C(=O)N2</smiles>

SU9516<smiles>NCCOc1cc(C(=O)Nc2cc(OCCN)c3ccccc3n2)nc(C(=O)Nc2cc(OCCN)c3ccccc3n2)c1</smiles>

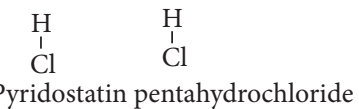<smiles>CCOC(=O)C1=C(N)Oc2ccc(Br)cc2C1C(C#N)C(=O)OCC</smiles>

HA14-1<smiles>CC(C)(C)C1=C/C(=C\C(C#N)=C(/N)S)C=CC1=O</smiles>

AG879<smiles>CC1(O)CC(c2nc(-c3ccc4ccc(-c5ccccc5)nc4c3)c3c(N)nccn23)C1</smiles>

OSI-906<smiles>CC(=O)c1cc2cnc(Nc3ccc(N4CCNCC4)cn3)nc2n(C2CCCC2)c1=O</smiles>

Palbociclib

FIGURE 7: PCNP and KIs ligands used in the docking study.

with the corresponding target macromolecule. However the results are preliminary and certainly need experimental confirmation, which will be conducted in near future via molecular biology studies but considering all these structural aspects and Glide score, meridine may possibly be a first choice as a PCNP lead molecule which could be exploited to design anticancer agents of future.

\section{Additional Points}

Binding models of PCNPs and KIs against different cancer macromolecules are shown in Figures S1 and S2, respectively, in Supplementary Material available online at http://dx.doi.org/10.1155/2016/5409387.

\section{Competing Interests}

The authors declare that there is no conflict of interests regarding the publication of this article.

\section{Acknowledgments}

Mr. Vikas Sharma is thankful to All India Council for Technical Education, India, for providing National Doctoral fellowship for Ph.D. research work (vide letter no. F. No. 14/AICTE/RIFD/NDF(Policy-I)/01/2012-13). Director of Institute of Pharmaceutical Sciences, Kurukshetra University, Kurukshetra, Haryana 136 119, India, is duly acknowledged for providing necessary research facilities. The authors sincerely acknowledge Schrodinger LLC., Portland, USA 
(https://www.schrodinger.com/), for providing software for research purpose.

\section{References}

[1] A. M. Brumby and E. R. Helena, "Using Drosophila melanogaster to map human cancer pathways," Nature Reviews Cancer, vol. 5, no. 8, pp. 626-639, 2005.

[2] J. P. Carini, F. Klamt, and V. L. Bassani, "Flavonoids from Achyrocline satureioides: promising biomolecules for anticancer therapy," RSC Advances, vol. 4, no. 7, pp. 3131-3144, 2014.

[3] G. M. Cragg and D. J. Newman, "Plants as a source of anticancer agents," Journal of Ethnopharmacology, vol. 100, no. 1-2, pp. 72-79, 2005.

[4] T. F. Molinski, "Marine pyridoacridine alkaloids: structure, synthesis, and biological chemistry," Chemical Reviews, vol. 93, no. 5, pp. 1825-1838, 1993.

[5] V. M. Srinivasan and C. S. Devi, "Novel anticancer compounds from marine actinomycetes: a review," Journal of Pharmacy Research, vol. 4, pp. 1285-1287, 2011.

[6] R. Ali, Z. Mirza, G. M. D. Ashraf et al., "New anticancer agents: recent developments in tumor therapy," Anticancer Research, vol. 32, no. 7, pp. 2999-3005, 2012.

[7] Y.-C. Shi and T.-M. Pan, "Beneficial effects of Monascus purpureus NTU 568-fermented products: a review," Applied Microbiology and Biotechnology, vol. 90, no. 4, pp. 1207-1217, 2011.

[8] S. Tabassum, M. Zaki, M. Afzal, and F. Arjmand, "Synthesis and characterization of $\mathrm{Cu}(\mathrm{II})$-based anticancer chemotherapeutic agent targeting topoisomerase I $\alpha$ : in vitro DNA binding, pBR322 cleavage, molecular docking studies and cytotoxicity against human cancer cell lines," European Journal of Medicinal Chemistry, vol. 74, pp. 509-523, 2014.

[9] S. N. e Zahra, N. A. Khattak, and A. Mir, "Comparative modeling and docking studies of p16ink4/cyclin D1/Rb pathway genes in lung cancer revealed functionally interactive residue of RB1 and its functional partner E2F1," Theoretical Biology \& Medical Modelling, vol. 10, pp. 1-9, 2013.

[10] K. M. Marshall, C. D. Andjelic, D. Tasdemir, G. P. Concepción, C. M. Ireland, and L. R. Barrows, "Deoxyamphimedine, a pyridoacridine alkaloid, damages DNA via the production of reactive oxygen species," Marine Drugs, vol. 7, no. 2, pp. 196209, 2009.

[11] F. J. Schmitz, S. K. Agarwal, S. P. Gunasekera, P. G. Schmidt, and J. N. Shoolery, "Amphimedine, new aromatic alkaloid from a pacific sponge, Amphimedon sp. Carbon connectivity determination from natural abundance carbon-13-carbon-13 coupling constants," Journal of the American Chemical Society, vol. 105, no. 14, pp. 4835-4836, 1983.

[12] T. F. Molinski and C. M. Ireland, "Varamines A and B, new cytotoxic thioalkaloids from Lissoclinum vareau," Journal of Organic Chemistry, vol. 54, no. 17, pp. 4256-4259, 1989.

[13] J.-L. Wang, D. Liu, Z.-J. Zhang et al., "Structure-based discovery of an organic compound that binds Bcl-2 protein and induces apoptosis of tumor cells," Proceedings of the National Academy of Sciences of the United States of America, vol. 97, no. 13, pp. 7124-7129, 2000.

[14] https://clinicaltrials.gov/ct2/show/NCT01560260.

[15] H. Uchiyama, Y. Sowa, M. Wakada et al., "Cyclin-dependent kinase inhibitor SU9516 enhances sensitivity to methotrexate in human T-cell leukemia Jurkat cells," Cancer Science, vol. 101, no. 3, pp. 728-734, 2010.
[16] K. I. E. McLuckie, M. Di Antonio, H. Zecchini et al., "Gquadruplex DNA as a molecular target for induced synthetic lethality in cancer cells," Journal of the American Chemical Society, vol. 135, no. 26, pp. 9640-9643, 2013.

[17] http://www.fda.gov/Drugs/InformationOnDrugs/ApprovedDrugs/ ucm487080.htm.

[18] M. H. Kang and C. P. Reynolds, "Bcl-2 inhibitors: targeting mitochondrial apoptotic pathways in cancer therapy," Clinical Cancer Research, vol. 15, no. 4, pp. 1126-1132, 2009.

[19] F. Manero, F. Gautier, T. Gallenne et al., "The small organic compound HAl4-1 prevents $\mathrm{Bcl}-2$ interaction with bax to sensitize malignant glioma cells to induction of cell death," Cancer Research, vol. 66, no. 5, pp. 2757-2764, 2006.

[20] H. Lu, D. J. Chang, B. Baratte, L. Meijer, and U. SchulzeGahmen, "Crystal structure of a human cyclin-dependent kinase 6 complex with a flavonol inhibitor, fisetin," Journal of Medicinal Chemistry, vol. 48, no. 3, pp. 737-743, 2005.

[21] P. S. Krishna, K. Vani, M. R. Prasad et al., "In -silico molecular docking analysis of prodigiosin and cycloprodigiosin as COX-2 inhibitors," SpringerPlus, vol. 2, article 172, 2013.

[22] Glide, Version 5.6, Schrodinger. LLC, New York, NY, USA, 2010.

[23] LigPrep, Version 2.4, Schrodinger. LLC, New York, NY, USA, 2010.

[24] MacroModel, Version 9.8, Schrodinger. LLC, New York, NY, USA, 2010.

[25] W. C. Still, A. Tempczyk, R. C. Hawley, and T. Hendrickson, "Semianalytical treatment of solvation for molecular mechanics and dynamics," Journal of the American Chemical Society, vol. 112, no. 16, pp. 6127-6129, 1990.

[26] U. Kaushik, V. Sharma, and V. Kumar, "Computation of pharmacophore models for the prediction of mitogen-activated protein kinase activated protein kinase-2 inhibitory activity of pyrrolopyridines," Medicinal Chemistry Research, vol. 21, no. 11, pp. 3777-3784, 2012.

[27] L. Shewchuk, A. Hassell, B. Wisely et al., "Binding mode of the 4-anilinoquinazoline class of protein kinase inhibitor: Xray crystallographic studies of 4-anilinoquinazolines bound to cyclin-dependent kinase 2 and p38 kinase," Journal of Medicinal Chemistry, vol. 43, no. 1, pp. 133-138, 2000.

[28] S. M. Haider, G. N. Parkinson, and S. Neidle, "Structure of a Gquadruplex-ligand complex," Journal of Molecular Biology, vol. 326, no. 1, pp. 117-125, 2003.

[29] H. Wei, A. J. Ruthenburg, S. K. Bechis, and G. L. Verdine, "Nucleotide-dependent domain movement in the ATPase domain of a human type IIA DNA topoisomerase," The Journal of Biological Chemistry, vol. 280, no. 44, pp. 37041-37047, 2005.

[30] M. Bruncko, T. K. Oost, B. A. Belli et al., "Studies leading to potent, dual inhibitors of Bcl-2 and Bcl-xL," Journal of Medicinal Chemistry, vol. 50, no. 4, pp. 641-662, 2007.

[31] M. Hasegawa, N. Nishigaki, Y. Washio et al., "Discovery of novel benzimidazoles as potent inhibitors of TIE-2 and VEGFR-2 tyrosine kinase receptors," Journal of Medicinal Chemistry, vol. 50, no. 18, pp. 4453-4470, 2007.

[32] U. Velaparthi, M. Wittman, P. Liu et al., "Discovery and initial SAR of 3-(1H-benzo[d]imidazol-2-yl)pyridin-2(1H)-ones as inhibitors of insulin-like growth factor 1-receptor (IGF-1R)," Bioorganic and Medicinal Chemistry Letters, vol. 17, no. 8, pp. 2317-2321, 2007.

[33] PHASE, Version 3.0, Schrodinger, LLC, NY, 2008. 

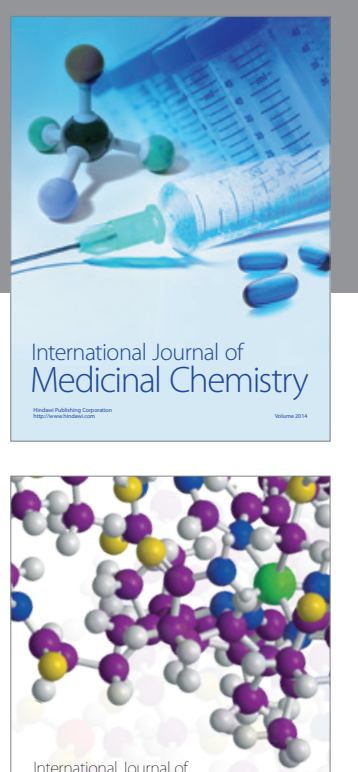

Carbohydrate Chemistry

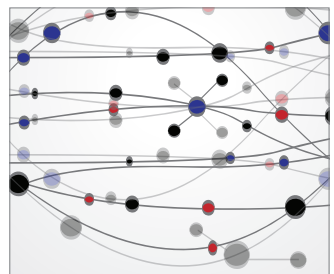

The Scientific World Journal
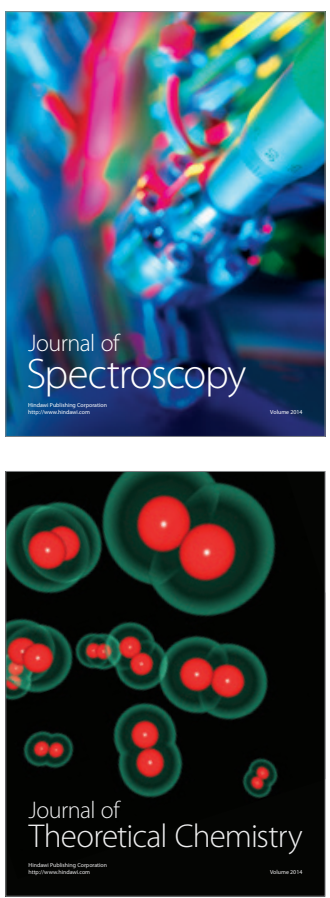
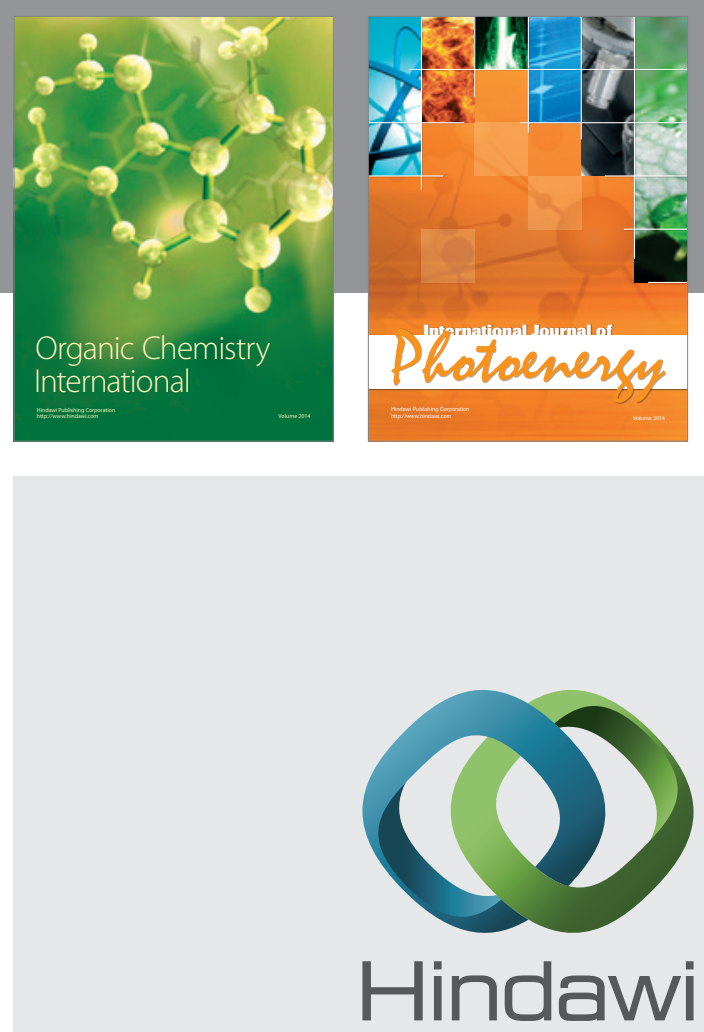

Submit your manuscripts at

http://www.hindawi.com

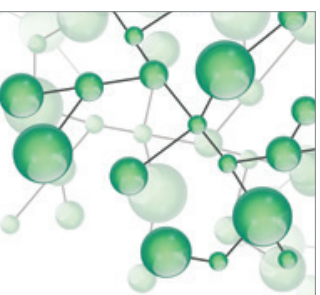

International Journal of

Inorganic Chemistry

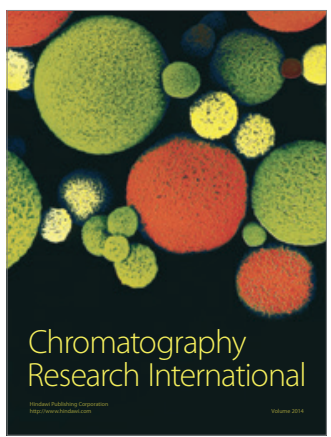

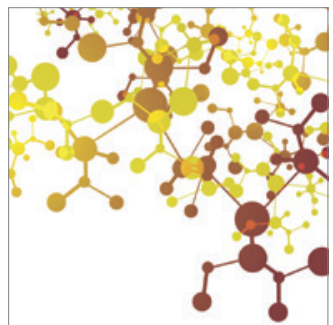

Applied Chemistry
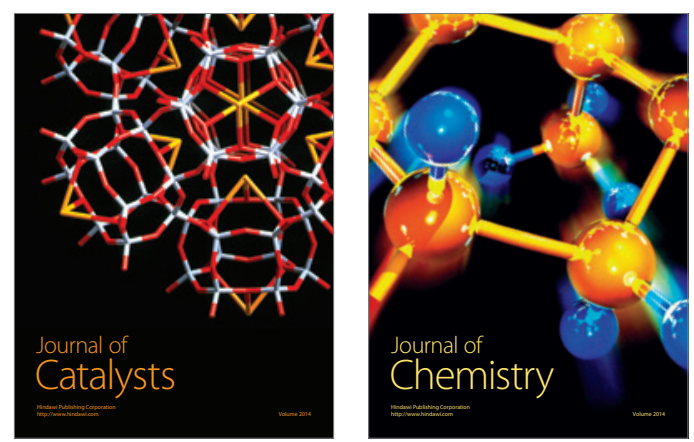
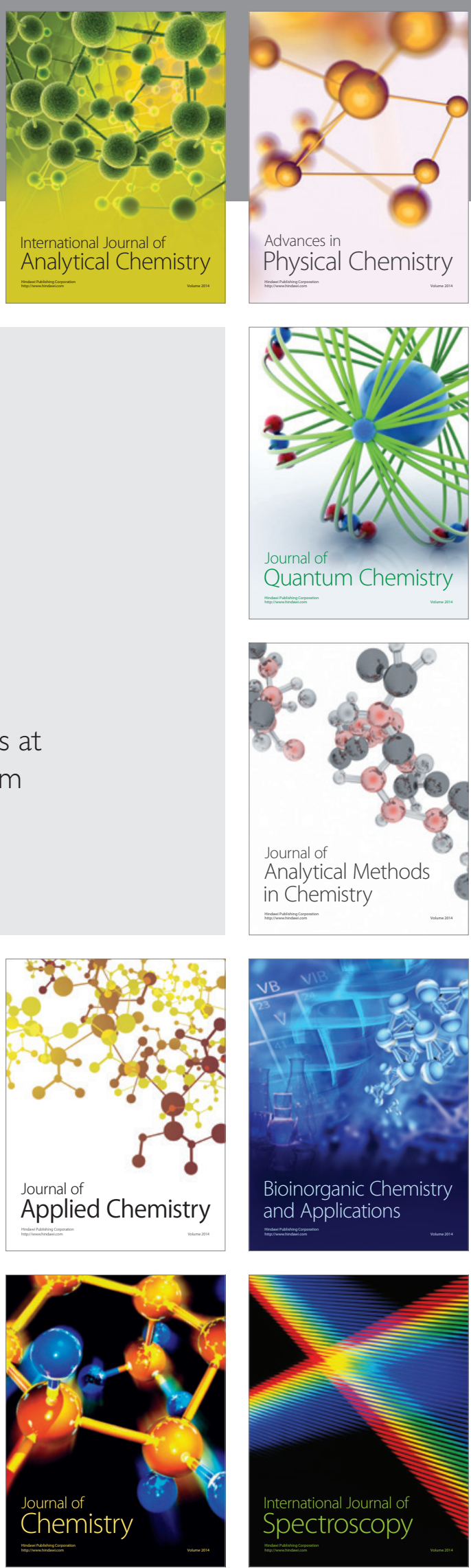